Coolabah, $\mathrm{Nr}$ 28, 2020, ISSN 1988-5946, Observatori: Centre d'Estudis Australians $i$ Transnacionals / Observatory: Australian and Transnational Studies Centre,

\title{
Homage from the Universitat de Barcelona
}

EACLALS will greatly miss his cheery face, which has delighted so many people in meetings all over the world. He made a great contribution to the workings of the association-- always helping us in difficult moments.

\section{Doireann Macdermott}

A little ditty from a Northern lassie to a Midlands Brummie:

Unpretentious and full of fun --

May we meet in Kingdom Come!

\section{Kathleen Firth}

\section{It was the warmth ...}

That is how I'll remember you, dear Geoff.

I didn't know you as well as some of my colleagues and now the chance has passed but the times we shared at conferences were always rewarding: your kind enquiry, your readiness to listen, your zest for living and knowing more, your eagerness to communicate and ability to convey scholarship with gargantuan gusto, laced with laughter.

Last seen in Ljubljana, the summer before you left us. The fire doesn't fade; we carry your embers.

\section{Jacqueline Hurtley}

